\title{
Determinants of performance in the hotel industry - an empirical analysis of Italy
}

\section{Stefano Bresciani*}

Faculty of Economics,

University of Torino,

Corso Unione Sovietica, 218 bis, 10134 Torino, Italy

Fax: +39-(0)11-6706052

Email: stefano.bresciani@unito.it

*Corresponding author

\author{
Alkis Thrassou and Demetris Vrontis \\ School of Business, \\ University of Nicosia, \\ 46 Makedonitissas Ave., P.O. Box 24005, 1700 Nicosia, Cyprus \\ Fax: 00357-22-353-722 \\ Email: thrassou.a@unic.ac.cy \\ Email: vrontis.d@unic.ac.cy
}

\begin{abstract}
Among the diverse services of the tourism sector, this paper concentrates on the hotel industry, which includes a set of companies that is homogenous in production and competitive setting. The hotel industry is a key component of the tourism sector since it is fundamental to the provision of all other tourism services. The aim of this research is to investigate the relationship between performance and its determinants in the Italian hotel industry. The findings aim to verify whether variables such as size, category and variety of services provided, positively influence the performance of the hotels. Methodologically, the research starts with theoretical work, comprising mainly a literature review on the subject, with special focus on the concept of performance in the hotel industry. Subsequently, it describes the empirical research undertaken, which includes the selection process of a sample of 450 hotels, and a questionnaire survey based on this sample. Finally, the research results are presented, which show a clear relationship between category and performance, while size and variety of the services provided do not appear to be linked to performance.
\end{abstract}

Keywords: hospitality industry; hotels; tourism; performance; strategy; Italy.

Reference to this paper should be made as follows: Bresciani, S., Thrassou, A. and Vrontis, D. (2015) 'Determinants of performance in the hotel industry an empirical analysis of Italy', Global Business and Economics Review, Vol. 17, No. 1, pp.19-34.

Biographical notes: Stefano Bresciani received his $\mathrm{PhD}$ in Business Administration in 2003 and worked as a Research Scholar in the ESCP-EAP, London and in the California State Polytechnic of Pomona, Los Angeles. He is currently a Researcher in Business Management at the Department of Management, University of Turin, where he teaches business management and innovation management. His main areas of research include business, 
innovation and strategic management, areas that he has published in many refereed journal articles, contributed chapters and books and presented papers to conferences on a global basis. He is also the Editor-in-Chief of Management and of Global Perspective on Engineering Management (GPEM). He is further, the Country Director for Italy of the EuroMed Research Business Institute (EMRBI) and the Chairman of the EMRBI Research Group on 'Multinational $\mathrm{R} \& \mathrm{D}$, embeddedness, and innovation'.

Alkis Thrassou is an Associate Professor at the School of Business, University of Nicosia, Cyprus. He holds a PhD in Strategic Marketing Management from the University of Leeds, UK and is also a Chartered Marketer, CIM, UK, a Chartered Builder, CIOB, UK and an Associate Research Fellow of EMRBI. From 1996 until 2002, he has worked as a Business and Project Manager for a construction consulting firm in Cyprus, leading teams of professionals through many projects of varying size and nature. In 2002, he joined the Marketing Department of the University of Nicosia, involving himself in various scholarly activities, lecturing on marketing-related subjects to both undergraduate and post-graduate students, and undertaking extensive research in the fields of strategic marketing, services and consumer behaviour. His work has been published in several scientific journals and books, and he retains strong ties with the industry, acting also as a consultant.

Demetris Vrontis is a Professor of Marketing and the Dean of the School of Business at the University of Nicosia in Cyprus. He is also a Visiting Scholar for Henley School of Management in the UK, a Visiting Professor for Vorarlberg University in Austria, a Visiting Research Fellow at the Manchester Metropolitan University in the UK and a Visiting Fellow at the Leeds Metropolitan University in the UK. His prime research interests are on international marketing, marketing planning, branding and marketing communications, areas that he has widely published in over 50 refereed journal articles, contributed chapters and cases in books and presented papers to conferences on a global basis. He is also the author of ten books in the areas of international marketing and marketing planning, is the editor of the EuroMed Journal of Business (EMJB) and the President of the EuroMed Research Business Institute (EMRBI).

This paper is a revised and expanded version of a paper entitled 'The determinants of performance in the Italian hotel industry: an empirical analysis' presented at EuroMed Academy of Business, 5th Annual EuroMed Conference on 'Building New Business Models for Success Through Innovation, Entrepreneurship, Competitiveness and Responsibility', Glion-Montreux, Switzerland, 4-5 October 2012.

\section{Introduction}

Services in general are highly heterogeneous and include a great variety of interesting, complex, and often highly innovative activities. Over the past few decades, their importance has steadily grown compared to that of tangible goods. In fact, the service industries comprise approximately more than $70 \%$ of aggregate production and employment in the Organisation for Economic Cooperation and Development (OECD) nations (OECD, 2012). 
Tourism services in particular have become of immense value to several countries and this is very important in the actual scenario, where multinational enterprises are competing to reach competitive advantages very quick (Bresciani and Ferraris, 2012; Bresciani et al., 2013). The latest World Economic Impact Report by the World Travel and Tourism Council (WTTC, 2012b) shows that world travel and tourism continues to grow in spite of continuing economic challenges. The direct contribution of Travel \& Tourism to GDP in 2011 was USD 1,972.8 bn (2.8\% of GDP). This is forecasted to rise by $2.8 \%$ to USD $2,028.2$ bn in 2012 . The figures primarily reflect the economic activity generated by industries such as hotels, travel agents, airlines and other passenger transportation services (excluding commuter services). It also includes, nonetheless, activities such as those of the restaurant and leisure industries that are directly supported by tourists. The direct contribution of Travel \& Tourism to GDP is expected to grow by $4.2 \%$ pa to USD 3,056.2 bn (3.0\% of GDP) by 2022 .

The total contribution of Travel \& Tourism to GDP (including wider effects from investment, the supply chain and induced income impacts) was USD 6,346.1 bn in 2011 (9.1\% of GDP) and is expected to grow by $2.8 \%$ to USD $6,526.9$ bn $(9.2 \%$ of GDP) in 2012 . It is forecasted to rise by $4.3 \%$ p.a. to USD $9,939.5$ bn by $2022(9.8 \%$ of GDP).

Travel \& Tourism generated 98,031,500 jobs directly in 2011 (3.3\% of total employment) and this is forecasted to grow by $2.3 \%$ in 2012 to $100,292,000$ (3.4\% of total employment). This includes employment by hotels, travel agents, airlines and other passenger transportation services (excluding commuter services). It also includes such activities as of the restaurant and leisure industries, directly supported by tourists. By 2022, Travel \& Tourism will account for 120,470,000 jobs directly, an increase of $1.9 \%$ p.a. over the next ten years. The total contribution of Travel \& Tourism to employment (including wider effects from investment, the supply chain and induced income impacts, see page 2) was 254,941,000 jobs in $2011(8.7 \%$ of total employment). This is forecasted to rise by $2.0 \%$ in 2012 to $260,093,000$ jobs ( $8.7 \%$ of total employment). By 2022, Travel \& Tourism is forecasted to support $327,922,000$ jobs $(9.8 \%$ of total employment), an increase of $2.3 \%$ p.a. over the same period.

The hotel industry is a key sector within the tourism industry since it is fundamental to the provision of all other tourism services; being the most basic requirement of tourists after they reach their destination (Orfila-Sintesa et al., 2005). Consequently, this study chooses the hotel industry as a suitable setting for the service economy. As there is a diversity of services in the tourism sector (Tremblay, 1998; Lopes Favero, 2011), we concentrated on the hotel industry, which includes companies that are homogenous in production and competitive setting. Moreover, this sector is deemed to be especially important because it is indispensable for the development of further services in a tourism destination; and because it carries, as shown above, a high relative weight in the totality of tourist expenditure.

This study focuses on the determinants of performance in the hotel industry, and presents empirical evidence on the contribution of determinants on performance. The aim of this research is to investigate the relationship between performance and its determinants in the Italian hotel industry. The findings aim to verify whether variables such as size, category and variety of services provided (Congr), positively influence the performance of the hotels. 
Methodologically, the research starts with theoretical work, comprising mainly a literature review on the subject, with special focus on the concept of performance in the hotel industry. Subsequently, it describes the empirical research undertaken, which includes the selection process of a sample of 450 hotels, and a questionnaire survey based on this sample. Finally, the research results are presented, which show a clear relationship between category and performance, while size and variety of the Congr do not appear to be linked to performance.

\section{Terminological definition and contextual framework}

A distinctive feature of hotel management theory concerns the complexity arising from the range of diverse activities undertaken (e.g., accommodation, food and beverage, laundry, etc.) within a building where service provision coincides with customer service consumption. The hotel manager is often criticised for trying to wear 'too many hats' (Rowe, 1993) and problems with poorly performing hotel restaurants are often attributed to differing core competencies required in hotels and restaurants (Hemmington and King, 2000). Outsourcing represents a way to manage this diversity problem (Gonzalez-Rivera, 2005).

Hotel is a part of the hospitality industry, which is an umbrella term for a broad variety of service industries including, but not limited to, hotels, restaurants and casinos. Hotel is often referred to as a 'home away from home'. If we consider the meaning of 'hotel' in the dictionary, a hotel is a building where you pay to have a room to sleep in and where you can eat meals or an establishment that provides paid lodging on a short-term basis.

In a different perspective, according to A.M. Sheela, the author of the book 'Economics of Hotel Management', hotel is a place where the tourist stops being the traveller and becomes a guest. Hotels usually offer a full range of accommodation and services, which may include suites, public dinning, banquet facilities, lounges and entertainment facilities. They are considered an industry whose main aim is also to make profits for the hoteliers, though this may change at times. Traditional hotels provide rooms, banquets and restaurants. Additionally, hotels make revenues from telephone call services, laundry services, travel services, internet services and recreational and entertainment activities.

Although significant attention has been directed to hotel outsourcing management issues in professional-oriented periodicals (e.g., hotel and motel management, lodging hospitality) as well as (more recently) by hospitality researchers (Goldman and Eyster, 1992; Hallam and Baum, 1996; Hemmington and King, 2000; Paraskevas and Buhalis, 2002; Espino-Rodríguez and Padrón-Robaina, 2004, 2005; Lam and Han, 2005; Lamminmaki, 2005, 2006, 2007), to date, limited accounting research interest was exhibited on hotel management issues. The few exceptions to this observation include Brignall et al. (1991), Collier and Gregory (1995a, 1995b), and Guilding (2003). Chenhall $(2003,2007)$ overall notes a growth in the importance of service industries and specifically cites the hospitality and tourism sectors as providing opportunities for future research. 


\section{Determinants of performance in the hotel industry}

Firms' performance relates to both external and internal factors: external, because firms compete in sectors and markets which influence strategy and results; internal, because firms have to decide every day on the correct way to operate, to allocate resources etc in order to manage business functions and reach goals (Bresciani et al., 2012).

For service firms, performance is not just related to balance sheets and financial data such as return on investment, return on sales, price variances, sales per employee, productivity and profit per unit of production (Ghalayini and Noble, 1996), but also to human resources, quality, image, brand awareness and other less tangible and/or quantifiable factors (Thrassou and Vrontis, 2009). Specifically, in the hotel industry, competition is based on the 'value' offerings of the service product, and it is consequently necessary to define and assess its various dimensions regarding hotel performance. Studies of performance indicators are discussed in the literature and measured largely by the firm's financial outcomes.

However, in the last 25 years, there has been a revolution in performance measurement (Neely and Bourne, 2000). Measurement approaches that relied only on financial results are now being replaced by more integrated systems that combine financial and non-financial indicators (Bergin-Seers and Jago, 2007). The most important consequence of performance not being quantified in financial terms only, is the indirect yet clear linkage of performance to customer satisfaction and quality (Ghalayini and Noble, 1996).

Indeed, hotel industry performance can be measured using occupancy performance, such as average occupancy rate: a practical alternative approach, in view of the reluctance of hotel managers to provide details on financial performance (Sun and $\mathrm{Lu}, 2005$ ). Moreover, revenue performance indicators themselves in the hotel industry, include total operating revenues, average production value per employee and others (Wassenaar and Stafford, 1991). Through these new approaches therefore and their combination, performance in the hotel industry has been studied by linking performance to both external and internal factors (Pereira-Moliner et al., 2010).

Some authors tried to find a correlation between performance and external factors. Tang and Jang (2009), for example, analysed the relationships between the performance of four tourism related industries (airlines, casinos, hotels, and restaurants) and GDP in the USA, showing no correlation between economic growth and industry performance. In the same direction, Arslanturk et al. (2010) do not find time-varying linkages between tourism receipts and economic growth. On the contrary, Brida et al. (2011) reviewed the main econometric studies that have addressed the analysis of causality between tourism and long-term economic growth, discovering that there is strong empirical evidence for the hypothesis of tourism's long-term economic growth. Similarly, Brida and Monterubbianesi (2010) found that tourism activity drives economic development in all the countries analysed. In fact economic, as well as strategic and branding synergies can be found between tourism and other industries (Rossi et al., 2012).

Other authors looked for a correlation between performance and internal factors. Gursoy and Swanger (2007) examined the internal strategic factors likely to influence company financial performance for service organisations, from the managers' perspectives; providing empirical evidence on the links between the internal strategic factors examined and financial performance of service organisations. Sainaghi (2010) investigating the hotel performance factors and using the balanced scorecard as a model 
to rationalise the main streams of research, put in evidence that in the literature, determining factors are generally looked for within the enterprise (strategy, production, marketing and organisation). Other authors analysed internal variables related to several firm functions, processes and operations, with a strong focus on strategy (Ingram, 1996; Ingram and Baum, 1997; Bresciani et al., 2010, 2012), marketing (Kim and Kim, 2005), production (Sigala, 2004; Barros, 2004) and organisation (Øgaard et al., 2008).

It is clearly visible therefore, that in existing literature, indicators used to measure these variables can be clustered into two main groups: balance sheet indicators and competitive/strategic indicators [i.e., employment, prices, revenue per available room (RevPar), rate of revenue growth, customer satisfaction]. Among all these studies and theoretical background, this research focuses on the determinants of RevPar; a performance metric in the hotel industry, which is calculated by dividing a hotel's total guestroom revenue by the room count and the number of days in the period being measured.

\section{The Italian context}

Hotel performance in Italy presents a generally positive picture, as measured by year-on-year percentage change for the year-to-date 2011, for the key performance indicators of occupancy, average daily rate and RevPar.

The 'Sesto rapporto sul sistema alberghiero in Italia' (Federalberghi, 2010) revealed that $20 \%$ of Italy's hotels are more than 100 years old, $80 \%$ more than 30 and that the majority of the hotels are small. On the other hand the quality has risen; in 1990, 1,500 were 4 or 5 star, in 2010 there were 5,445. The increase in quality though, was accompanied by an increase in bookings, though. In fact, the report shows that in the last ten years demand has actually fallen by $5.2 \%$. Increases in running costs coupled with a fall in demand have put Italy's hotel industry in a minor crisis, while lacking the funds to maintain, renovate or innovate to remain competitive; a phenomenon observed in other Italian industries as well (Bresciani et al., 2012).

Travel \& Tourism Economic Impact 2012 - Italy (WTTC, 2012a), puts in evidence that the direct contribution of Travel \& Tourism to GDP in 2011 was EUR 51.4 bn $(3.3 \%$ of GDP) and forecasted to fall by $1.6 \%$ to EUR 50.6 bn in 2012 . This primarily reflects the economic activity generated by industries such as hotels, travel agents, airlines and other passenger transportation services (excluding commuter services); but it also includes activities such as those of the restaurant and leisure industries directly supported by tourists. The direct contribution of Travel \& Tourism to GDP is expected to grow by $1.9 \%$ p.a. to EUR 61.2 bn (3.5\% of GDP) by 2022 .

The total contribution of Travel \& Tourism to GDP (including wider effects from investment, the supply chain and induced income impacts) was EUR $136.1 \mathrm{bn}$ in 2011 (8.6\% of GDP) and is expected to grow by $2.2 \%$ to EUR 133.1 bn ( $8.5 \%$ of GDP) in 2012. It is forecasted to rise by $1.6 \%$ p.a. to EUR 156.0 bn by 2022 ( $8.8 \%$ of GDP).

Travel \& Tourism generated 868,500 jobs directly in 2011 (3.8\% of total employment) and this is forecasted to fall by $1.3 \%$ in 2012 to 857,000 (3.8\% of total employment). This includes employment by hotels, travel agents, airlines and other passenger transportation services (excluding commuter services); but it also includes activities such as those of the restaurant and leisure industries directly supported by tourists. By 2022, Travel \& Tourism will account for 996,000 jobs directly, an increase of 
$1.5 \%$ p.a. over the next ten years. The total contribution of Travel \& Tourism to employment (including wider effects from investment, the supply chain and induced income impacts) was 2,231,500 jobs in 2011 (9.7\% of total employment). This is forecasted to fall by $2.5 \%$ in 2012 to $2,176,000$ jobs ( $9.6 \%$ of total employment). By 2022, Travel \& Tourism is forecast to support $2,386,000$ jobs $(10.4 \%$ of total employment), an increase of $0.9 \%$ p.a. over the period.

Visitor exports are a key component of the direct contribution of Travel \& Tourism. In 2011, Italy generated EUR 30.5 bn in visitor exports. In 2012, this is expected to fall by $0.9 \%$, and the country is expected to attract $43,591,000$ international tourist arrivals. By 2022, international tourist arrivals are forecasted to total 52,958,000, generating expenditure of EUR $32.7 \mathrm{bn}$; an increase of $0.8 \%$ p.a.

According to the World Tourism Organization Network (WTON, 2011), with more than 43.2 million tourists a year, Italy is the fourth highest tourist earner, and fifth most visited country in the world, behind France (76.0 million), Spain (55.6 million), USA (49.4 million), and China (46.8). People mainly come to Italy for its rich art, cuisine, history, fashion, culture, beautiful coastlines and beaches, mountains and ancient monuments, spread throughout the territory.

\section{Hypotheses development}

Choosing which products and what kind of services to provide is a critical decision that each hotel has to make. To measure the choices made, literature underlines the importance of monitoring the category (i.e., number of stars), the size (i.e., number of rooms), chain branding, Congr (i.e., meeting/congress spaces), and location/destination.

It is further possible to separate the different streams of the literature in order to better investigate possible relationships. Several authors looked for a relation between size, economies of scale and performance (Israeli, 2002; Barros, 2004; Pine and Philips, 2005; Claver-Cortés et al., 2007; Assaf and Cvelbar, 2010; Claver-Cortés et al., 2010). Following their findings, it is possible to formulate the following hypothesis:

H1 A positive correlation exists between hotel dimension and performance.

Star rating (Stars) was further used as a determinant of performance by several researchers, who have often found positive correlation between the number of stars and performance (Ingram and Roberts, 2000; Israeli, 2002; Danziger et al., 2006; Tarí et al., 2010). As a consequence, it is possible to formulate the following hypothesis:

$\mathrm{H} 2$ A positive correlation exists between the stars-rating (and therefore quality) and performance.

Some authors use the presence of meeting rooms, congress spaces and other conference facilities as additional measures of performance. For example, Claver-Cortés et al. (2006) and Urtasun and Gutíerrez (2006) find a correlation between the range of Congr and the quality of the hotel. Following these authors, it is possible to formulate the following hypothesis:

H3 A positive correlation exists between the service provided and performance.

Table 1 puts in evidence the correlation matrix between the variables we consider: RevPar, Stars, dimension (Dim), chain brand affiliation (Chain), and Congr. 
Table 1 Correlation matrix

\begin{tabular}{llccccc}
\hline & & RevPar & Stars & Dim & Chain & Congr \\
\hline RevPar & Pearson correlation & 1 & $.932^{* *}$ & $.551^{* *}$ & .027 & $.375^{* *}$ \\
& Sig. (one-tailed) & & .000 & .000 & .392 & .000 \\
& $\mathrm{~N}$ & 104 & 104 & 104 & 104 & 104 \\
\hline \multirow{2}{*}{ Stars } & Pearson correlation & $.932^{* *}$ & 1 & $.593^{* *}$ & -.033 & $.398^{* *}$ \\
& Sig. (one-tailed) & .000 & & .000 & .372 & .000 \\
& $\mathrm{~N}$ & 104 & 104 & 104 & 104 & 104 \\
\hline \multirow{2}{*}{ Dim } & Pearson correlation & $.551^{* *}$ & $.593^{* *}$ & 1 & .026 & $.341^{* *}$ \\
& Sig. (one-tailed) & .000 & .000 & & .397 & .000 \\
& $\mathrm{~N}$ & 104 & 104 & 104 & 104 & 104 \\
\hline Chain & Pearson correlation & .027 & -.033 & .026 & 1 & .072 \\
& Sig. (one-tailed) & .392 & .372 & .397 & & .234 \\
& $\mathrm{~N}$ & 104 & 104 & 104 & 104 & 104 \\
\hline \multirow{6}{*}{ Congr } & Pearson correlation & $.375^{* *}$ & $.398^{* *}$ & $.341^{* *}$ & .072 & 1 \\
& Sig. (one-tailed) & .000 & .000 & .000 & .234 & \\
& $\mathrm{~N}$ & 104 & 104 & 104 & 104 & 104 \\
\hline
\end{tabular}

Note: ${ }^{* *}$ Correlation is significant at the 0.01 level (one-tailed).

Source: Research analysis

Finally, many authors (including Baum and Haveman, 1997; Urtasun and Gutíerrez, 2006; Shoval et al., 2011) use variables such as 'location' or 'destination' to look for a relation with performance. The hotel industry generally recognises the advantages of a central district location, resulting in higher demand, pricing ability, and profitability, but in other cases there is evidence of negative effects of agglomeration and competition among centrally located hotels (Lee and Jang, 2012). The case of Italy, however, is special because all the attractions (art, cuisine, history, fashion and culture, coastline/beaches, mountains, ancient monuments, etc.) are widely spread throughout the country. For this reason there is little sense in looking for a correlation between location and performance (though this is possible at a completely localised level).

In the same way, and since the correlation matrix (Table 1) does not show a correlation between 'Chain' and RevPar, the research does not investigate the relation between these two variables. Additionally, empirical evidence shows at times a positive relationship between Chain and results (Ingram and Roberts, 2000; Yeung and Lau, 2005), but sometimes no link (Damonte et al., 1997; Israeli, 2002). The importance of Chain is primarily presented in studies conducted by Ingram (1996) and Ingram and Baum (1997). 


\section{Research methodology}

The data used in the analysis are taken from the 'World Economic Impact Report' by the WTTC (2012b) and 'Sesto rapporto sul sistema alberghiero in Italia' (Federalberghi, 2010). The research was conducted in two separate phases. In the first phase a sample of 450 hotels was selected, including only those which are representative of the region and which have a Stars of 3 or more (on a rising scale of one to five). In the second phase a structured questionnaire was sent during 2011 to the 450 hotels of the sample. Two hundred eight hotels responded with acceptably completed questionnaires (a successful response rate of $41.60 \%$ ).

This research applies a revisited version of the model of analysis used by Sainaghi (2010). The author identified RevPar determinants of individual firms located in a destination analysing a sample of 72 hotels operating in the 3 to 5 stars range. The model was subsequently and consequently synthesised using Dim, Stars and Congr as Independent Variables and RevPar as Dependent Variable. So:

$$
\text { RevPar }=\beta_{0}+\beta_{1} \text { Dim }+\beta_{2} \text { Stars }+\beta_{3} \text { Congr }
$$

where

RevPar a performance metric in the hotel industry

Dim number of available rooms

Stars number of stars of the hotel - category

Congr binary variable which detects the presence of meeting rooms and congress spaces $(1=$ yes; $2=$ no $)$.

Sevaral studies use RevPar as indicator of the hotel performance (Kim and Kim, 2005; Cho and Erdem, 2006; Namasivayam et al., 2007; Campos Blanco et al., 2011) due to the fact that it is not an economic variable and it catches the importance of competitive/strategic indicators.

\section{$7 \quad$ Research results}

Based on the survey research, data on size, category, and Congr were collected. Table 2 presents the characteristics of the hotels in the sample.

Table 2 Hotels

\begin{tabular}{lcc}
\hline \multicolumn{3}{c}{ Independent variables } \\
\hline Size/dimension (dim) & Hotels number & $\%$ \\
\hline Less than 50 rooms & 126 & $60.6 \%$ \\
From 50 to 79 rooms & 56 & $26.9 \%$ \\
More than 79 rooms & 26 & $12.5 \%$ \\
Total & 208 & $100.0 \%$ \\
\hline
\end{tabular}

Source: Primary research results 
Table 2 Hotels (continued)

\begin{tabular}{lcc}
\hline \multicolumn{3}{c}{ Independent variables } \\
\hline Category (stars) & Hotels number & $\%$ \\
\hline 5 stars & 6 & $2.9 \%$ \\
4 stars & 48 & $23.1 \%$ \\
3 stars & 154 & $74.0 \%$ \\
Total & 208 & $100.0 \%$ \\
\hline Services provided (congr) & & \\
\hline Congressual hotels & 114 & $54.8 \%$ \\
No congressual hotels & 94 & $45.2 \%$ \\
Total & 208 & $100.0 \%$ \\
\hline
\end{tabular}

Source: Primary research results

The data (Table 1) show some significant correlations between independent variables. However, it was decided that these variables are maintained in the model because this kind of correlations are typical of the hotel industry. To confirm this choice, a multicollinearity test was conducted and the results show: a variance inflation index (VIF) of 1.65, which is under the level (3.0) suggested by literature (Hair et al., 2005); and a condition index of a maximum of 20.43, which is, also in this case, under the level (25.0) suggested by literature (Belsley et al., 2004).

Table 3 Tests of significance

\begin{tabular}{|c|c|c|c|c|c|c|}
\hline \multicolumn{7}{|c|}{ Model summary ${ }^{\mathrm{b}}$} \\
\hline Model & $R$ & $R$-square & \multicolumn{2}{|c|}{ Adjusted R-square } & \multicolumn{2}{|c|}{ Std. error of the estimate } \\
\hline 1 & $.932^{\mathrm{a}}$ & .868 & \multicolumn{2}{|c|}{.864} & \multicolumn{2}{|c|}{7.5917} \\
\hline \multicolumn{7}{|c|}{$A N O V A^{b}$} \\
\hline Model & & $\begin{array}{l}\text { Sum of } \\
\text { squares }\end{array}$ & $d f$ & $\begin{array}{l}\text { Mean } \\
\text { square }\end{array}$ & $F$ & Sig. \\
\hline \multirow[t]{3}{*}{1} & Regression & $37,930.303$ & 3 & $12,643.434$ & 219.373 & $.000^{\mathrm{a}}$ \\
\hline & Residual & $5,763.436$ & 100 & 57.634 & & \\
\hline & Total & $43,693.739$ & 103 & & & \\
\hline
\end{tabular}

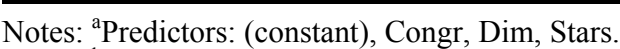

${ }^{\mathrm{b}}$ Dependent variable: RevPAR

Source: Research results

Applying the model, it was possible to find significant statistical results $(P=.000)$ which explain $86.8 \%$ of the RevPar variability $\left(R^{2}=0.868\right)$. This means that the three dependent variables (Size/Dim, Category and Congr) together explain $86.8 \%$ of the variability of the performance (RevPar) of the hotels. Moreover, the ANOVA test shows an acceptable result $(P<0.0001)$ (Table 3$)$.

Table 4 shows the results of the regression. Columns B and beta put in evidence the sign of the correlation between the independent variables and RevPar. Category (Stars) and Congr are positively correlated to performance, which means that the higher the 
category and Congr, the better the performance. On the contrary, there is a negative sign for the Dim. However, looking at the Sig. column it is possible to note that Stars alone is a useful variable to explain the variability of RevPar. So, it is possible to assume that the results positively answer $\mathrm{H} 2$, i.e., that there is a positive correlation between the stars rating (and so quality) and performance. On the contrary, no significant correlation between size/Dim and performance is found. No significant correlation is found also between Congr and performance, so $\mathrm{H} 1$ and $\mathrm{H} 3$ have to be rejected.

Table 4 Regression results

\begin{tabular}{|c|c|c|c|c|c|c|c|c|}
\hline \multicolumn{9}{|c|}{ Coefficients $^{\mathrm{a}}$} \\
\hline \multirow{2}{*}{\multicolumn{2}{|c|}{ Model }} & \multicolumn{2}{|c|}{$\begin{array}{c}\text { Unstandardised } \\
\text { coefficients }\end{array}$} & \multirow{2}{*}{$\begin{array}{c}\begin{array}{c}\text { Standardised } \\
\text { coefficients }\end{array} \\
\text { Beta }\end{array}$} & \multirow[t]{2}{*}{$t$} & \multirow[t]{2}{*}{ Sig. } & \multicolumn{2}{|c|}{$\begin{array}{l}\text { Collinearity } \\
\text { statistics }\end{array}$} \\
\hline & & $B$ & Std. error & & & & Tolerance & $V I F$ \\
\hline \multirow[t]{4}{*}{1} & (Constant) & -47.524 & 5.255 & & -9.044 & .000 & & \\
\hline & Stars & 37.236 & 1.866 & .932 & 19.956 & .000 & .605 & 1.652 \\
\hline & Dim & -.003 & .038 & -.003 & -.075 & .940 & .636 & 1.573 \\
\hline & Congr & .227 & 1.647 & .006 & .138 & .891 & .825 & 1.212 \\
\hline
\end{tabular}

Note: ${ }^{a}$ Dependent variable: RevPAR.

Source: Research results

\section{Conclusions, managerial implications and further research}

The results prove that category (Stars) is the only determinant of hotel performance among those investigated. Category has a positive correlation with performance, which means that hotels of higher quality exhibit a greater capacity to handle employment and prices, yielding a value higher in RevPAR.

Underlying the strong correlation between Stars and size/Dim (0.593) it can also be said that the hotels of higher category also tend to be larger and thus show greater efficiency. The stars also have a high correlation with conference services (0.398), allowing a more efficient management of employment and prices. During low season it is possible to enhance these services to attract specific segments of the business (meetings, incentives, congress). In addition, the sale of additional services (conference spaces) tends to increase the revenues of the structure, reflected as a higher RevPAR.

It is also interesting to interpret the assumptions that have not been verified by the analysis; and in particular the absence of a significant correlation between size/Dim and performance (H1), and between Congr and performance (H3). Size/Dim does not show a significant correlation with performance; a result which may seem strange, given the strong emphasis that usually arises on the economies of scale and specialisation. One possible explanation is location. The larger structures tend to be located in areas not central or, often, very remote.

Finally, Congr have a positive correlation, but not significant, with the performance. This evidence is rather unique. Indeed, it is reasonable to expect that this appeals to seasonality and adjusts employment and revenue growth, generating an improvement in RevPAR; and therefore one would expect that the sign is not simply positive, but that the correlation is also significant. One possible explanation may be related to the difficulties 
facing hotels during the low season. Moreover, congress services are often used by local businesses that do not arise overnight. This reduces benefits in terms of employment and prices.

Generally speaking, from the data collected in the study and their analysis, it is evident that quality is a key cultural factor pervading a hotel's management philosophy and approach to operations. This factor is underscored by the importance of the hotel Stars system. The Stars system signifies that hotels are independently branded with respect to their quality. A priori, it is to be expected that higher quality hotels will have more sophisticated management systems to support their higher quality service delivery. As maintenance of high quality of service is expected to be more important to higher Stars hotels, it follows that high Stars hotels will implement relatively sophisticated systems to assist in the decision-making process and to control the quality of service provided by subcontractors.

The constant increase of demand of touristic services therefore, and the request for higher standards by the guests, has fuelled competition among hospitality suppliers and highlighted how the attraction of the touristic destination is influenced by the standards of the Congr by the local hotels. In this context, providing high quality services and improving customer satisfaction are widely recognised as fundamental factors boosting the performances of companies in the hotel and tourism industry (Dominici and Guzzo, 2010). Hotels with good service quality will ultimately improve their profitability.

The research results though, coupled with the theoretical research findings do surface some additional strategic considerations. Firstly, the affiliation with international chain brands is trend that cannot be overlooked and therefore hotels will need at some point to make a strategic choice between independence and conformity to specifications of international groups; and in conjunction decide also the degree to which the country-specific attributes shall or not overshadow the international ones (Vrontis et al., 2006, 2009; Vrontis and Thrassou, 2007). Secondly, quality and client satisfaction may be referred to in a 'static' and objective manner throughout the research; they are terms nonetheless that are both 'dynamic' and subjective. It is thus necessary for hotels to have constant and updated understanding of customers' expectations and definitions/attributes of quality, as these are not only frequently very different to what hotel managers believe them to be, but also changing with an increasing pace (Thrassou and Vrontis, 2009). Finally, the very fact that consumer demands, attitudes, expectations, evaluation processes and factors change incessantly, increasingly strengthens the need for hotels to develop strategies that are flexible and 'reflexive' enough to automatically adapt accordingly (Thrassou et al., 2012)

On a catalectic note, the research has strengthened the belief that performance must be linked to indicators of less tangible nature. Additionally, it is clear that these indicators are very much linked to concepts such as 'quality', 'value' and 'satisfaction'. Terms that are highly subjective and in need of definition regarding the specific industry. It is thus recommended that further research concentrates on the study of these concepts with its primary aim to understand and elaborate them for the hotel industry, both from the guest's perspective and the hotel's.

Ultimately, a shift must occur in hotel management philosophy, from the quantifiable and mechanistic approach to the value-based strategic marketing one. 


\section{References}

Arslanturk, Y., Balcilar, M. and Ozdemir, Z.A. (2011) 'Time-varying linkages between tourism receipts and economic growth in a small open economy', Economic Modelling, Vol. 28, Nos. 1-2, pp.664-671.

Assaf, A. and Cvelbar, L.K. (2010) 'The performance of the Slovenian hotel industry: evaluation post-privatisation', International Journal of Tourism Research, Vol. 12, No. 5, pp.462-471.

Barros, C.P. (2004) 'A stochastic cost frontier in the Portuguese hotel industry', Tourism Economics, Vol. 10, No. 2, pp.177-192.

Baum, J.A.C. and Haveman, H.A. (1997) 'Love thy neighbour? Differentiation and agglomeration in the Manhattan hotel industry 1898-1990', Administrative Science Quarterly, Vol. 42, No. 2 , pp.304-338.

Belsley, D.A., Kuh, E. and Welsch, R.E. (2004) Regression Diagnostics - Identifying Influential Data and Sources of Collinearity, John Wiley \& Sons, New Jersey.

Bergin-Seers, S. and Jago, L. (2007) 'Performance measurement in small motels in Australia', Tourism and Hospitality Research, Vol. 37, No. 2, pp.144-155.

Bresciani, S. and Ferraris, A. (2012) Imprese Multinazionali: Innovazione e Scelte Localizzative, Maggioli, Santarcangelo di Romagna, RN.

Bresciani, S., Thrassou, A. and Vrontis, D. (2012) 'Human resource management - practices, performance and strategy in the Italian hotel industry', World Review of Entrepreneurship, Management and Sustainable Development, Vol. 8, No. 4, pp.405-423.

Bresciani, S., Vrontis, D. and Thrassou, A. (2010) 'Human resource management - practices, performance and strategy in the Italian hotel industry', in Vrontis, D., Weber, Y., Kaufmann, R. and Tarba, S. (Eds.): Business Developments Across Countries and Cultures, Proceedings of the 3rd EuroMed Conference, EuroMed Press, Cyprus, 4-5 November, pp.155-173.

Bresciani, S., Vrontis, D. and Thrassou, A. (2013) 'Change through innovation in family businesses: evidence from an Italian sample', World Review of Entrepreneurship, Management and Sustainable Development, Vol. 9, No. 2, pp.195-215.

Brida, J.G. and Monterubbianesi, D.P. (2010) 'Causality between economic growth and tourism expansion: empirical evidence for $\mathrm{m}$ so me Colombian regions', Journal of Tourism Challenges and Trends, Vol. 3, No. 1, pp.153-164.

Brida, J.G., Pereyra, J.S., Such, M.J. and Pulina, M. (2011) Causality Between Tourism and Long-Term Economic Growth: A Critical Review of the Econometric Literature, MPRA Paper No. 37332, April.

Brignall, T.J., Fitzgerald, L., Johnston, R. and Silvestro, R. (1991) 'Product costing in service organizations', Management Accounting Research, Vol. 2, No. 4, pp.227-248.

Campos Blanco, A., Oehmichen, A. and Frood, S. (2011) 'European hotel development - focus on budget hotels', Journal of Retail \& Leisure Property, Vol. 9, No. 5, pp.373-379.

Chenhall, R. (2003) 'Management control systems design within its organizational context: findings from contingency-based research and directions for the future', Accounting, Organizations and Society, Vol. 28, Nos. 2-3, pp.127-168.

Chenhall, R. (2007) 'Theorizing contingencies in management control systems research', in Chapman, C., Hopwood, A. and Shields, M. (Eds.): Handbook of Management Accounting Research, Elsevier, Amsterdam.

Cho, S.H. and Erdem, M. (2006) 'Employee relation programs and hotel performance: impact on turnover, labour productivity, and RevPAR', Journal of Human Resources in Hospitality \& Tourism, Vol. 5, No. 2, pp.55-68.

Claver-Cortés, E., Molina-Azorìn, J.F. and Pereira, J. (2007) 'The impact of strategic behaviours on hotel performance', International Journal of Contemporary Hospitality Management, Vol. 19, No. 1, pp.6-20. 
Claver-Cortés, E., Molina-Azorin, J.F. and Pereira-Moliner, J. (2006) 'Strategic groups in the hospitality industry: intergroup and intragroup performance differences in Alicante Spain', Tourism Management, Vol. 27, No. 6, pp.1101-1116.

Collier, P. and Gregory, A., (1995a) 'Investment appraisal in service industries: a field study analysis of the UK hotels sector', Management Accounting Research, Vol. 6, No. 1, pp.33-57.

Collier, P. and Gregory, A., (1995b) 'Strategic management accounting: a UK hotel sector case study', International Journal of Contemporary Hospitality Management, Vol. 7, No. 1, pp.16-21.

Damonte, L.T., Rompf, P., Domke, D. and Bahl, R. (1997) 'Brand affiliation and property size effects on measures of performance in lodging properties', Hospitality Research Journal, Vol. 20, No. 3, pp.1-16.

Danziger, S., Israeli, A. and Bekerman, M. (2006) 'The relative role of strategic assets in determining customer perceptions of hotel room price', International Journal of Hospitality Management, Vol. 25, No. 1, pp.129-145.

Dominici, G. and Guzzo, R. (2010) 'Customer satisfaction in the hotel industry: a case study from Sicily', International Journal of Marketing Studies, November, Vol. 2, No. 2, pp.3-12.

Espino-Rodríguez, T. and Padrón-Robaina, V. (2004) 'Outsourcing and its impact on operational objectives and performance: a study of hotels in the Canary Islands', International Journal of Hospitality Management, Vol. 23, No. 3, pp.287-306.

Espino-Rodriguez, T. and Padron-Robaina, V. (2005) 'A resource-based view of outsourcing and its implications for organizational performance in the hotel sector', Tourism Management, Vol. 26, No. 5, pp.707-721.

Federalberghi (2010) Sesto Rapporto sul sistema alberghiero in Italia, Federalberghi.

Ghalayini, A. and Noble, J. (1996) 'The changing basis of performance measurement', International Journal of Operations and Production Management, Vol. 16, No. 8, pp.63-80.

Goldman, K.L. and Eyster, J.J. (1992) 'Hotel F\&B leases: the view from the restaurant', The Cornell Hotel and Restaurant Administration Quarterly, October, Vol. 32, No. 5, pp.72-83.

Gonzalez-Rivera, G. (2005) 'Outsourcing: three long run predictions', Global Business and Economics Review, Vol. 7, Nos. 2/3, pp.226-233.

Guilding, C. (2003) 'Hotel owner/operator structures: implications for capital budgeting process', Management Accounting Research, Vol. 14, No. 3, pp.179-199.

Gursoy, D. and Swanger, J. (2007) 'Performance-enhancing internal strategic factors and competencies: impacts on financial success', International Journal of Hospitality Management, Vol. 26, No. 1, pp.213-227.

Hair, J.F. Jr., Black, W.C., Babin, B., Anderson, R. and Tatham, R. (2005) Multivariate Data Analysis, 5th ed., Prentice-Hall, Upper Saddle River, NJ.

Hallam, G. and Baum, T. (1996) 'Contracting out food and beverage operations in hotels: a comparative study of practice in North America and the United Kingdom', International Journal of Hospitality Management, Vol. 15, No. 1, pp.41-50.

Hemmington, N. and King, C. (2000) 'Key dimensions of outsourcing hotel food and beverage services', International Journal of Contemporary Hospitality Management, Vol. 12, No. 4, pp.256-261.

Ingram, P. (1996) 'Organizational form as a solution to the problem of credible commitment: the evolution of naming strategies among US hotel chains, 1896-1980', Strategic Management Journal, Vol. 17, No. SI, pp.85-98.

Ingram, P. and Baum, J.A.C. (1997) 'Chain affiliation and the failure of Manhattan hotels, 1898-1980', Administrative Science Quarterly, Vol. 42, No. 1, pp.68-102.

Ingram, P. and Roberts, P.W. (2000) 'Friendships among competitors in the Sydney hotel industry', American Journal of Sociology, Vol. 106, No. 2, pp.387-423. 
Israeli, A.A. (2002) 'Star rating and corporate affiliation: their influence on room price and performance of hotels in Israel', International Journal of Hospitality Management, Vol. 21, No. 4, pp.405-424.

Kim, H.B. and Kim, W.G. (2005) 'The relationship between brand equity and firms' performance in luxury hotels and chain restaurants', Tourism Management, Vol. 26, No. 4, pp.549-560.

Lam, T. and Han, M. (2005) 'A study of outsourcing strategy: a case involving the hotel industry in Shanghai, China', International Journal of Hospitality Management, Vol. 24, No. 1, pp.41-56.

Lamminmaki, D. (2005) 'Why do hotels outsource? An investigation using asset specificity', International Journal of Contemporary Hospitality Management, Vol. 17, No. 6, pp.516-528.

Lamminmaki, D. (2006) 'Outsourcing in the hotel industry: a management accounting perspective', in Harris, P. and Mongiello, M. (Eds.): Accounting and Financial Management: Developments in the International Hospitality Industry, Butterworth-Heinemann.

Lamminmaki, D. (2007) 'Outsourcing in Australian hotels: a transaction cost economics perspective', Journal of Hospitality and Tourism Research, Vol. 31, No. 1, pp.73-110.

Lee, S.K. and Jang, S.C.S. (2012) 'Premium or discount in hotel room rates? The dual effects of a central downtown location', Cornell Hospitality Quarterly, Vol. 53, No. 2, pp.165-173.

Lopes Favero, L.P. (2011) 'Urban amenities and dwelling house prices in Sao Paulo, Brazil: a hierarchical modelling approach', Global Business and Economics Review, Vol. 13, No. 2, pp.147-167.

Namasivayam, K., Miao, L. and Zhao, X. (2007) 'An investigation of the relationships between compensation practices and firm performance in the US hotel industry', International Journal of Hospitality Management, Vol. 26, No. 3, pp.574-587.

Neely, A. and Bourne, M. (2000) 'Why measurement initiatives fail', Measuring Business Excellence, Vol. 5, No. 2, pp.6-13.

OECD (2012) Services Statistics [online] http://www.oecd.org (accessed 10/09/2012).

Øgaard, T., Marnburg, E. and Larsen, S. (2008) 'Perceptions of organizational structure in the hospitality industry: consequences for commitment, job satisfaction and perceived performance', Tourism Management, Vol. 29, No. 4, pp.661-671.

Orfila-Sintesa, F., Crespi-Cladera, R. and Martinez-Ros, E. (2005) 'Innovation activity in the hotel industry: evidence from Balearic Islands', Tourism Management, Vol. 26, No. 6, pp.851-865.

Paraskevas, A. and Buhalis, D. (2002) 'Outsourcing IT for small hotels', The Cornell Hotel and Restaurant Administration Quarterly, Vol. 43, No. 2, pp.27-39.

Pereira-Moliner, J., Claver-Cortés, E. and Molina-Azorín, J.F. (2010) 'Strategy and performance in the Spanish hotel industry', Cornell Hospitality Quarterly, Vol. 51, No. 4, pp.513-528.

Pine, R. and Phillips, P.A. (2005) 'Performance comparisons of hotels in China', International Journal of Hospitality Management, Vol. 24, No. 1, pp.57-73.

Rossi, M., Vrontis, D. and Thrassou, A. (2012) 'Wine business in a changing competitive environment - strategic and financial choices of Campania Wine Firms', International Journal of Business and Globalisation, Vol. 8, No. 1, pp.112-130.

Rowe, M. (1993) 'If you can't beat 'em, join'em', Lodging Hospitality, Vol. 49, No. 13, pp.57-59.

Sainaghi, R. (2010) 'Hotel performance: state of the art', International Journal of Contemporary Hospitality Management, Vol. 22, No. 7, pp.920-952.

Shoval, N., McKercher, B., Ng, E. and Birenboim, A. (2011) 'Hotel location and tourist activity in cities', Journal Annals of Tourism Research, Vol. 38, No. 4, pp.1594-1612.

Sigala, M. (2004) 'Using data envelopment analysis for measuring and benchmarking productivity in the hotel sector', Journal of Travel and Tourism Marketing, Vol. 16, No. 2, pp.39-60.

Sun, S. and Lu, W. (2005) 'Evaluating the performance of the Taiwanese hotel industry using a weight slacks-based measure', Asia-Pacific Journal of Operational Research, Vol. 22, No. 4, pp.487-512.

Tang, C.H. and Jang, S.C. (2009) 'The tourism-economy causality in the United States: a sub-industry level examination', Tourism Management, Vol. 30, No. 4, pp.553-558. 
Tarí, J.J., Claver-Cortés, E., Pereira-Moliner, J. and Molina-Azorín, J.F. (2010) 'Levels of quality and environmental management in the hotel industry: their joint influence on firm performance', International Journal of Hospitality Management, Vol. 29, No. 3, pp.500-510.

Thrassou, A. and Vrontis, D. (2009) 'A new consumer relationship model: the marketing communications application', Journal of Promotion Management, Vol. 15, No. 4, pp.499-521.

Thrassou, A., Vrontis, D., Chebbi, H. and Yahiaoui, D. (2012) 'A preliminary strategic marketing framework for new product development', Journal of Transnational Management, Vol. 17, No. 1, pp.21-44.

Tremblay, P. (1998) 'The economic organization of tourism', Annals of Tourism Research, Vol. 25, No. 4, pp.837-859.

Urtasun, A. and Gutíerrez, I. (2006) 'Hotel location in tourism cities: Madrid 1936-1998', Annals of Tourism Research, Vol. 33, No. 2, pp.382-402.

Vrontis, D. and Thrassou, A. (2007) 'Adaptation vs. standardisation in international marketing the country-of-origin effect', Journal of Innovative Marketing, Vol. 3, No. 4, pp.7-21. ISSN: 1814-2427-Business Perspectives.

Vrontis, D., Thrassou, A. and Lamprianou, I. (2009) 'International marketing adaptation versus standardisation of multinational companies', International Marketing Review, Vol. 26, Nos. 4/5, pp.477-500.

Vrontis, D., Thrassou, A. and Vignali, C. (2006) 'The country-of-origin effect, on the purchase intention of apparel - opportunities \& threats for small firms', International Journal of Entrepreneurship and Small Business, Vol. 3, Nos. 3/4, pp.459-476.

Wassenaar, K. and Stafford, E.R. (1991) 'The lodging index: an economic indicator for the hotel/motel industry', Journal of Travel Research, Vol. 30, No. 1, pp.11-21.

World Tourism Organization Network (2011) Compendium of Tourism Statistics, World Tourism Organization.

World Travel and Tourism Council (2012a) Travel \& Tourism Economic Impact 2012 - Italy, World Travel and Tourism Council [online] http://www.wttc.org (accessed 10/09/2012).

World Travel and Tourism Council (2012b) World Economic Impact Report, World Travel and Tourism Council [online] http://www.wttc.org (accessed 10/09/2012).

Yeung, P.K. and Lau, C.M. (2005) 'Competitive actions and firm performance of hotels in Hong Kong’, International Journal of Hospitality Management, Vol. 24, No. 4, pp.611-633. 